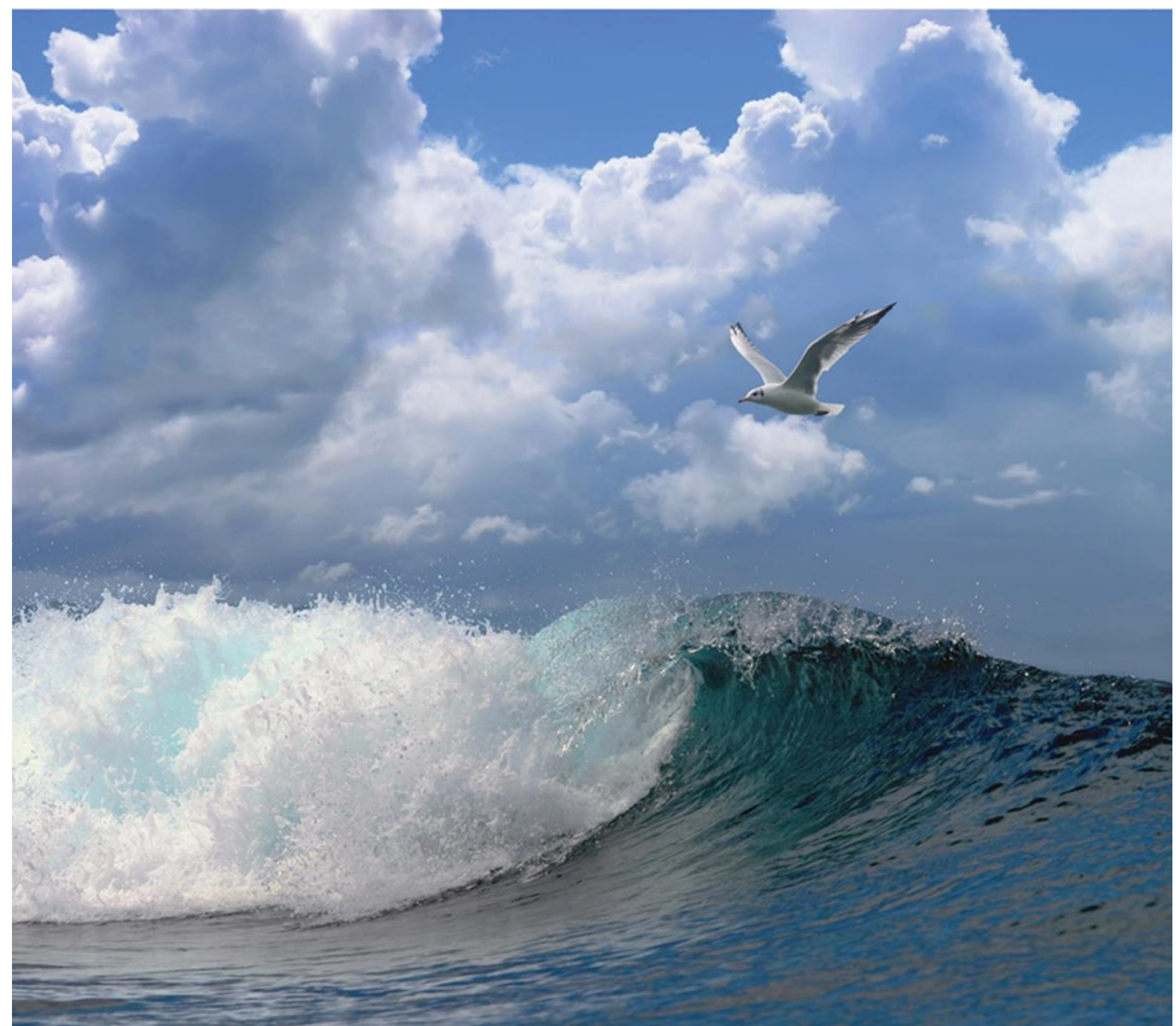

\title{
Evaluatie bijvangst tijdens Hot Spot Net Catching
}




\section{Evaluatie bijvangst tijdens}

\section{Hot Spot Net Catching}

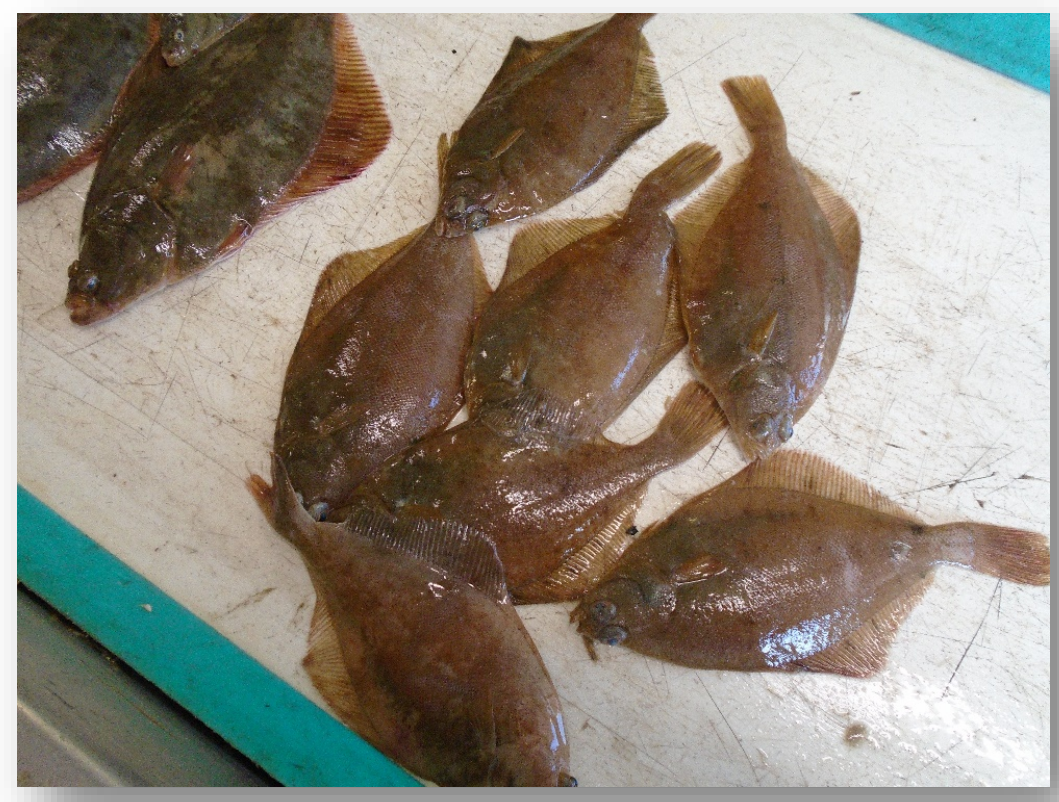

Auteur: Michelle Boonstra

Wageningen Marine Research 
Keywords: vuilvissen, MSC Zoë, bijvangt evaluatie,

\author{
Opdrachtgever: Michiel Visser \\ Rijkswaterstaat Zee \& Delta \\ Ministerie van Infrastructuur en Waterstaat \\ Lange Kleiweg 34 | 2288 GK Rijswijk \\ Postbus 2232 | 3500 GE Utrecht
}

Dit rapport is gratis te downloaden van https://doi.org/10.18174/517871

Wageningen Marine Research verstrekt geen gedrukte exemplaren van rapporten.

Wageningen Marine Research is ISO 9001:2015 gecertificeerd.

Foto omslag: Frits van Dellen

\title{
(c) Wageningen Marine Research
}

Wageningen Marine Research, instituut binnen de rechtspersoon Stichting

Wageningen Research, hierbij vertegenwoordigd door Dr. M.C.Th. Scholten, Algemeen directeur

KvK nr. 09098104,

WMR BTW nr. NL 8113.83.696.B16.

Code BIC/SWIFT address: RABONL2U

IBAN code: NL 73 RABO 0373599285
Wageningen Marine Research aanvaardt geen aansprakelijkheid voor gevolgschade, noch voor schade welke voortvloeit uit toepassingen van de resultaten van werkzaamheden of andere gegevens verkregen van Wageningen Marine Research. Opdrachtgever vrijwaart Wageningen Marine Research van aanspraken van derden in verband met deze toepassing.

Alle rechten voorbehouden. Niets uit deze uitgave mag weergegeven en/of gepubliceerd worden, gefotokopieerd of op enige andere manier gebruikt worden zonder schriftelijke toestemming van de uitgever of auteur. 


\section{Inhoud}

1 Kennisvraag $\quad 4$

2 Methoden $\quad 5$

2.1 Pilot $\quad 5$

2.2 Vervolg 25

3 Resultaten $\quad 6$

$\begin{array}{lll}3.1 & \text { Beschermde soorten } & 6\end{array}$

3.2 Hoeveelheid vangst 6

$\begin{array}{ll}3.3 & \text { Lengtes }\end{array}$

$4 \quad$ Conclusies en aanbevelingen $\quad 10$

$5 \quad$ Kwaliteitsborging $\quad 12$

$\begin{array}{lr}\text { Literatuur } & 13\end{array}$ 


\section{$1 \quad$ Kennisvraag}

Rijkswaterstaat heeft WMR verzocht om de registratie en evaluatie van bijvangst tijdens de pilot "Hot Spot Net Catching" (HSNC) te verzorgen en tijdens het vervolg op de pilot voort te zetten. Tijdens de pilot werden twee schepen ingezet om met boomkorren met een maaswijdte van $120 \mathrm{~mm}$ gericht het debris, afkomstig van het incident met de MSC Zoë, op te vissen. Tijdens het vervolg is er nog maar met één schip gevist.

Het doel van de registratie en evaluatie is het vaststellen van het al dan niet aanwezig zijn van beschermde soorten in de vangst, in het kader van soortenbescherming onderdeel van de Wet natuurbescherming. Daarnaast geeft het inzicht in eventuele andere ecologische impact van het inzetten van visnetten voor het opruimen van debris. Dit ten behoeve van het beoordelen of de gebruikte methode geschikt is om voor langere tijd in te zetten om het afval van MSC Zoë op te ruimen.

De concrete vragen zijn:

- In welke mate is er sprake van bijvangst van beschermde soorten?

- Zijn de vangsten van niet beschermde soorten van een orde die impact zou kunnen hebben op de populatie ontwikkeling?

- In het geval van een van het bovenstaande; welke aanpassingen aan het tuig en/of vismethode zouden dit kunnen voorkomen/veranderen?

- Wat is het risico bij vervolg?

WMR is gevraagd aan de hand van de beschikbare gegevens een deskundige beoordeling en advies te geven. Desalniettemin is het belangrijk te melden dat gezien de beperkte betrokkenheid, tijd en omvang van dit project er niet gekomen zal worden tot een wetenschappelijk kwalitatief oordeel.

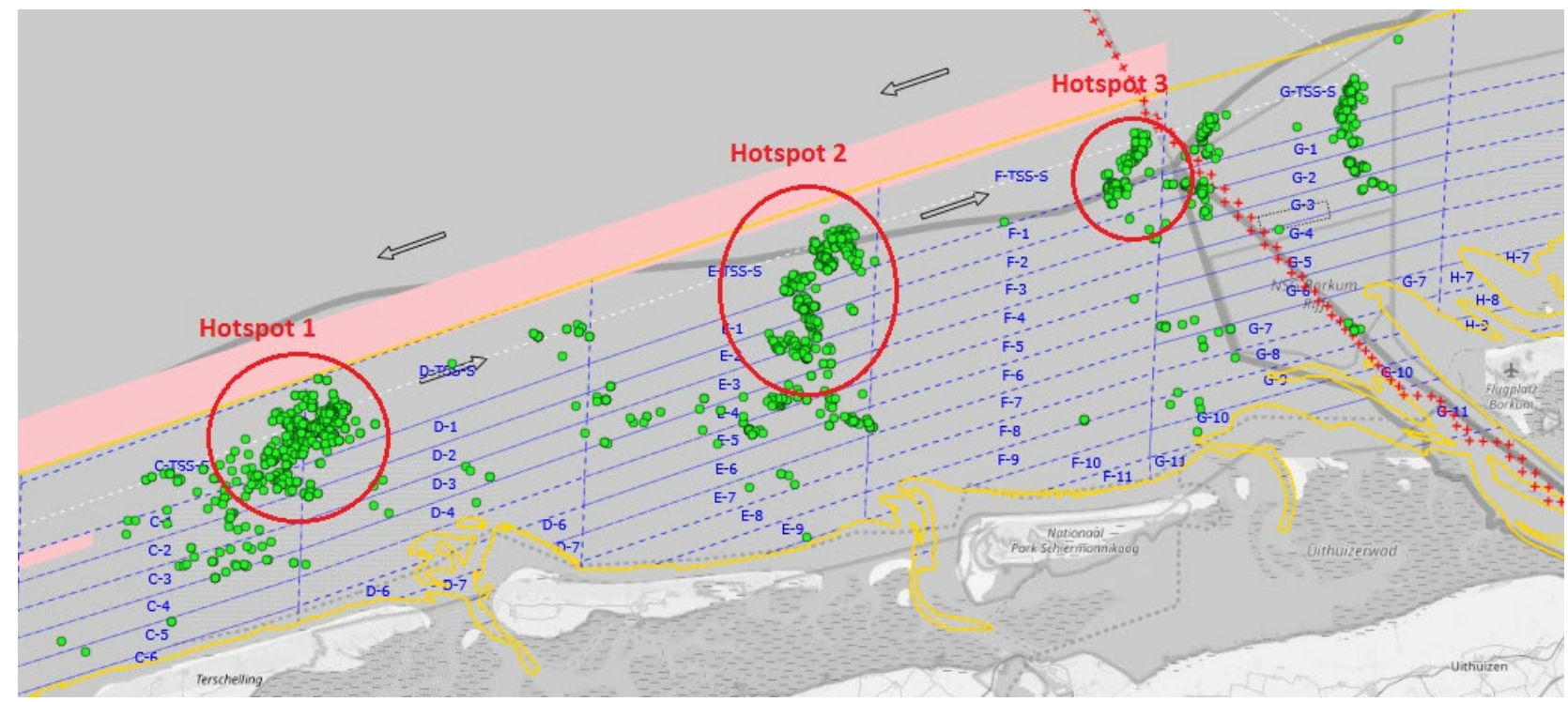

Figuur 1. De drie hot spots van Pilot $\operatorname{HSNC}(1,2$ en 3) 


\section{$2 \quad$ Methoden}

\section{$2.1 \quad$ Pilot}

Tijdens de dertien dagen durende pilot in juli zijn aan boord gegevens verzameld van 125 "trekken" door een onafhankelijk waarnemer van RWS. Tijdens twee van die dertien dagen is er daarnaast een gecertificeerd waarnemer van WMR aan boord geweest voor het verzamelen van meer uitgebreide gegevens. Gegevens zijn genoteerd op verschillende formulieren, aangeleverd door RWS en WMR. Ook zijn er foto's overlegd van de vangsten. Waarnemers is verzocht bij het aantreffen van beschermde soorten een extra notitie te maken, met een (geschatte) lengte en een duidelijk foto van het individu. Het ging daarbij om de volgende soorten of soortsgroepen; haaien, roggen, salmoniden, steur, fint, elft, Noordzeehouting, zeeprik of zeezoogdieren.

\section{$2.2 \quad$ Vervolg}

Tijdens het vervolg van 20 augustus en 15 september zijn er 123 "trekken" gedaan. Bij de vervolg reizen waren geen waarnemers aanwezig, maar noteerde de vissers zelf de vangst. Dit gebeurde op dezelfde wijze als dat de RWS waarnemer dit deed; het noteren van aantallen per soort, per trek op een treklijst. Lengtes van vissen zijn tijdens deze reis niet gemeten. Ook benthos is tijdens deze reis niet op soort gebracht en genoteerd. Verder zijn er foto's genomen voor eventuele identificatie, verificatie achteraf en is er via whatsapp contact onderhouden over de vangst en eventuele bijzonderheden hierin. Hierdoor kon er indien nodig direct overlegd en gehandeld worden. 


\section{Resultaten}

\subsection{Beschermde soorten}

Een van de aspecten van de evaluatie van de bijvangst tijdens het afvalvissen is de bijvangst van beschermde soorten. Beschermde soort volgens de definitie van de Wet natuurbescherming zijn niet waargenomen in de vangst tijdens de pilot. Een soort had een vermelding op de Rode lijst (tabel 1); de wijting - gevoelig (Tien et al., 2016). Buiten dat dit de laagste status op de rode lijst is, gaat het hier ook om een soort die slechts een enkele keer gevangen is (tabel 2). Geen enkele soort in de vangst tijdens de pilot heeft een vermelding op de "Initial OSPAR List of Threatened and/or Declining Species and Habitats" (OSPAR, 2008-6).

Tijdens het vervolg zijn er vijf soorten gevangen die tijdens de pilot nog niet gevangen waren (tabel 2). Een daarvan, de gewone zeehond was al geruime tijd dood, en laten we om die reden buiten beschouwing. Voor de haai was er door de bemanning geen soort genoteerd en omdat er ook geen foto van is gemaakt, kan achteraf niet worden vastgesteld om welke soort haai het gaat en welke status deze soort heeft. Wel weten we dat de overlevingskans van haaien en roggen, over het algemeen hoger is dan die van de meeste andere vissen (Ellis et al., 2017; Enever et al., 2009; Mandelman et al. 2013). De stekelrog (Raja clavata) heeft een vermelding op zowel op de OSPAR lijst als op de Nederlandse rode lijst als kwetsbaar (OSPAR, 2008-6; Tien et al., 2016). Ook de makreel (Scomber scombrus) heeft deze vermelding op de Nederlandse rode lijst. In al deze gevallen gaat het om een enkele vangst (tabel 2).

\subsection{Hoeveelheid vangst}

Er is tijdens de pilot bij 98 van de 125 trekken een geschat totaalgewicht aan visvangst genoteerd. Tijdens het vervolg is er geen totaal gewicht voor visvangst genoteerd. Gemiddeld werd er tijdens de pilotfase $1,6 \mathrm{~kg}$ vis (inclusief inktvis en kreeft) per trek gevangen.

Voor de top zeven meest gevangen soorten vis tijdens deze pilot zijn het aantal gevangen vissen per uur gegeven in tabel 3. Om dit in een context te plaatsen zijn ernaast uit de commerciële visserij bekende gediscarde (of ongewenste) aantallen per uur van die soorten weergegeven met een vergelijkbaar tuig; boomkor met een maaswijdte tussen 100-119 mm (Verkempynck et al., 2018). Daarnaast het aantal kilo dat per uur wordt aangevoerd met boomkor of sumwing met een maaswijdte groter dan $100 \mathrm{~mm}$ of met boomkor met $80 \mathrm{~mm}$ in 2018 (omgerekend uit agrimatienet. $\mathrm{nl}$ ). Deze twee getallen samen geven een impressie van de totale vangst per uur, welke vergeleken kan worden met de geregistreerde aantallen in de pilot.

In de eerste kolom staat $\mathrm{F}_{\mathrm{MSY}}$, wat wil zeggen of de visserijdruk op deze soort in dit gebied boven of onder het gewenste niveau Maximum Sustainable Yield (MSY) ligt. Alleen bij tong is de visserijdruk op dit moment hoger dan het gewenste niveau. Van de rode poon en het harnasmannetje zijn dergelijk gegevens niet bekend.

Als we kijken naar het verschil in aantallen per uur tussen de pilot en vervolg fase dan valt eigenlijk vooral op dat er tijdens de pilot meer schar en meer harnasmannetjes zijn gevangen. Vanwege de kwaliteit en omvang van de data is dit niet statistisch getest. 
Tabel 1. Lijst van soorten die tijdens het project HSNC gevangen en geregistreerd zijn, met daarbij het aantal gevangen individuen per uur.In dit project is in totaal 215 uur gevist. Daarnaast wordt de vermelding op de Nederlandse rode lijst en de Initial OSPAR List of Threatened and/or Declining Species and Habitats gegeven.

\begin{tabular}{ll}
\hline Nederlandse naam & \#etenschappelijke naam \\
& TOTAAL \\
\hline
\end{tabular}

\begin{tabular}{|c|c|c|c|c|}
\hline Schar & Limanda limanda & 5,8 & & \\
\hline Tarbot & Scophthalmus maximus & 2,1 & & \\
\hline Schol & Pleuronectes platessa & 1,9 & & \\
\hline Rode poon & Chelidonichthys Iucerna & 1,6 & & \\
\hline Bot & Platichthys flesus & 2,0 & & \\
\hline Tong & Solea solea & 0,8 & & \\
\hline Harnasmannetje & Agonus cataphractus & 1,1 & & \\
\hline Schurftvis & Arnoglossus laterna & 0,1 & & \\
\hline Pitvis & Callionymus lyra & 0,04 & & \\
\hline Griet & Scophthalmus rhombus & 0,03 & & \\
\hline Dwergtong & Buglossidium luteum & 0,01 & & \\
\hline Kleine zeenaald & Syngnathus rostellatus & 0,01 & & \\
\hline Zandspiering & Ammodytes sp. & 0,01 & & \\
\hline Grauwe poon & Eutrigla gurnardus & 0,1 & & \\
\hline Rasterpitvis & Callionymus reticulatus & 0,004 & & \\
\hline Wijting & Merlangius merlangus & 0,004 & gevoelig & \\
\hline Zeedonderpad & Myoxocephalus scorpius & 0,05 & & \\
\hline Mul & Mullus surmuletus & 0,009 & & \\
\hline Stekelrog & Raja clavata & 0,004 & kwetsbaar & ja \\
\hline Makreel & Scomber scombrus & 0,004 & kwetsbaar & \\
\hline Haai & Onbekend & 0,004 & $?$ & $?$ \\
\hline Gewone pijlinktvis & Loligo sp. & 0,04 & & \\
\hline Dwergpijlinktvis & Alloteuthis subulata & 0,004 & & \\
\hline Europese kreeft & Homarus gammarus & 0,4 & & \\
\hline
\end{tabular}


Tabel 2. Lijst van soorten die zijn aangetroffen in de vangsten van de Pilot en het Vervolg van HSNC, inclusief het aantal waargenomen individuen en het percentage van de trekken waarin de soort gevonden werd. De benthos soorten (gearceerd) zijn in slechts 15 trekken op naam gebracht en geteld en dus ook ten opzichte daarvan uitgedrukt.

\begin{tabular}{|c|c|c|c|c|c|}
\hline Nederlandse naam & Wetenschappelijke naam & $\begin{array}{l}\text { \# Individuen geteld } \\
\text { PILOT }\end{array}$ & $\begin{array}{l}\text { \% trekken } \\
\text { aanwezig } \\
\text { PILOT }\end{array}$ & $\begin{array}{l}\text { \#Individuen } \\
\text { geteld VERVOLG }\end{array}$ & $\begin{array}{l}\text { \% trekken } \\
\text { aanwezig } \\
\text { VERVOLG }\end{array}$ \\
\hline Schar & Limanda limanda & 822 & & 86,5428 & 75,6 \\
\hline Tarbot & Scophthalmus maximus & 171 & & 63,5280 & 67,5 \\
\hline Schol & Pleuronectes platessa & 201 & & 56,3200 & 71,5 \\
\hline Rode poon & Chelidonichthys lucerna & 127 & & 54,0211 & 67,5 \\
\hline Bot & Platichthys flesus & 110 & & 50,0325 & 76,4 \\
\hline Tong & Solea solea & 69 & & 31,794 & 41,5 \\
\hline Harnasmannetje & Agonus cataphractus & 206 & & 24,626 & 10,6 \\
\hline Schurftvis & Arnoglossus laterna & 23 & & 9,50 & 0 \\
\hline Pitvis & Callionymus lyra & 9 & & 4,80 & 0 \\
\hline Griet & Scophthalmus rhombus & 5 & & 4,02 & 1,6 \\
\hline Dwergtong & Buglossidium luteum & 2 & & 1,60 & 0 \\
\hline Kleine zeenaald & Syngnathus rostellatus & 2 & & 1,60 & 0 \\
\hline Zandspiering & Ammodytes sp. & 2 & & 1,61 & 0,8 \\
\hline Grauwe poon & Eutrigla gurnardus & 1 & & 0,826 & 4,1 \\
\hline Rasterpitvis & Callionymus reticulatus & 1 & & 0,80 & 0 \\
\hline Wijting & Merlangius merlangus & 1 & & 0,80 & 0 \\
\hline Zeedonderpad & Myoxocephalus scorpius & 4 & & 1,67 & 5,7 \\
\hline Mul & Mullus surmuletus & 0 & & 2 & 0,8 \\
\hline Stekelrog & Raja clavata & 0 & & 1 & 0,8 \\
\hline Makreel & Scomber scombrus & 0 & & 1 & 0,8 \\
\hline Haai & Onbekend & 0 & & 1 & 0,8 \\
\hline Gewone pijlinktvis & Loligo sp. & 5 & & 3,23 & 2,4 \\
\hline Dwergpijlinktvis & Alloteuthis subulata & 1 & & 0,80 & 0 \\
\hline Europese kreeft & Homarus gammarus & 21 & & 11,965 & 17,1 \\
\hline Fluwelen zwemkrab & Necora puber & 1 & & 6,7 & \\
\hline Gewone heremietkreeft & Pagurus bernhardus & 7 & & 20,0 & \\
\hline Helmkrab & Corystes cassivelaunus & 22 & & 20,0 & \\
\hline Hooiwagenkrab & Macropodia rostrata & 2 & & 6,7 & \\
\hline Noordzeekrab & Cancer pagurus & 94 & & 60,0 & \\
\hline Strandkrab & Carcinus maenas & 309 & & 40,0 & \\
\hline Zwemkrab & Liocarcinus holsatus & 3044 & & 100,0 & \\
\hline Kamster & Astropecten irregularis & 297 & & 60,0 & \\
\hline Slangster & Ophiura sp. & 119 & & 40,0 & \\
\hline Zeester & Asterias rubens & 3624 & & 100,0 & \\
\hline Blauwe haarkwal & Cyanea lamarckii & 1 & & 6,7 & \\
\hline Kompaskwal & Chrysaora hysoscella & 7 & & 20,0 & \\
\hline
\end{tabular}


Tabel 3. De top 7 meest gevangen soorten met daarbij de huidige visserijdruk ten opzichte van het gewenste limiet volgens het laatste ICES advies (ICES, 2017, 2019 a-d), waar V = onder MSY limiet, $X=$ boven MSY limiet en ? = geen gegevens. Het aantal gevangen individuen per uur tijdens de pilot en tijdens de vervolg fase, ernaast ter vergelijking gemiddelden uit de commerciële visserij.

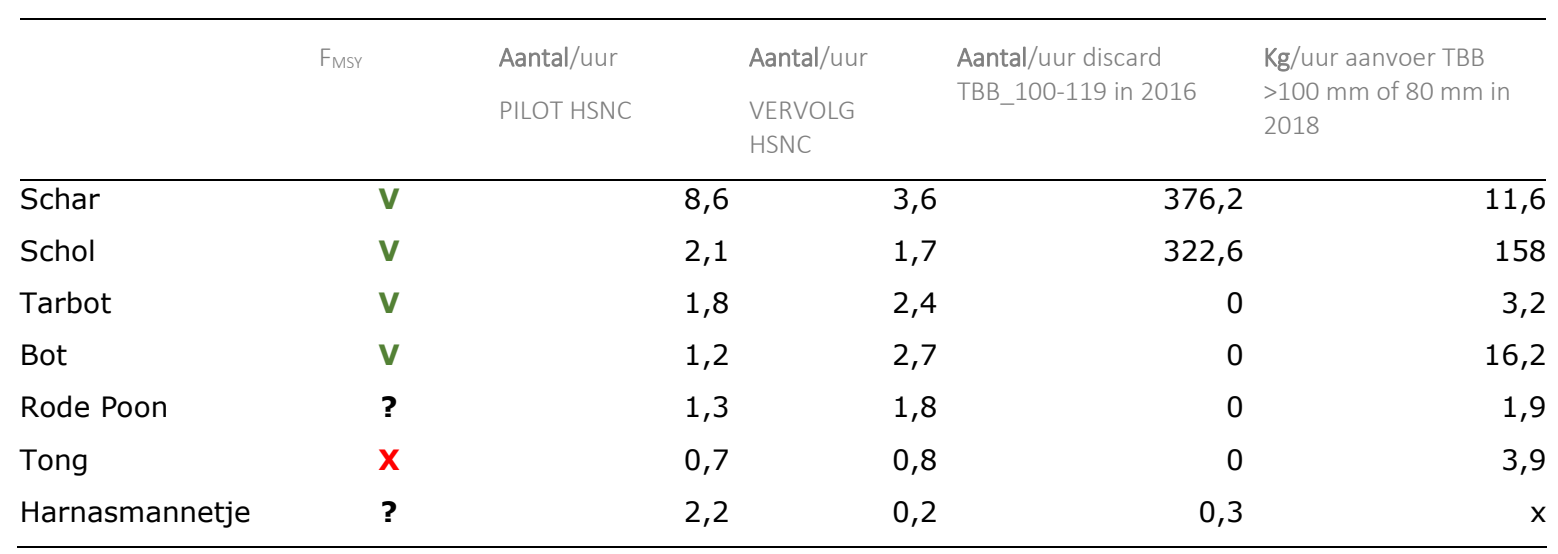

\subsection{Lengtes}

Gezien de geringe hoeveelheid gemeten lengtes van vissen, is alleen de lengte verdeling van de schar weergegeven $(\mathrm{N}=101)$. Ter vergelijking is de lengte verdeling weergegeven van gediscarde schar gevangen met een vergelijkbaar tuig, een boomkor met een maaswijdte 100-119 mm. De range van lengtes komt grotendeels overeen.
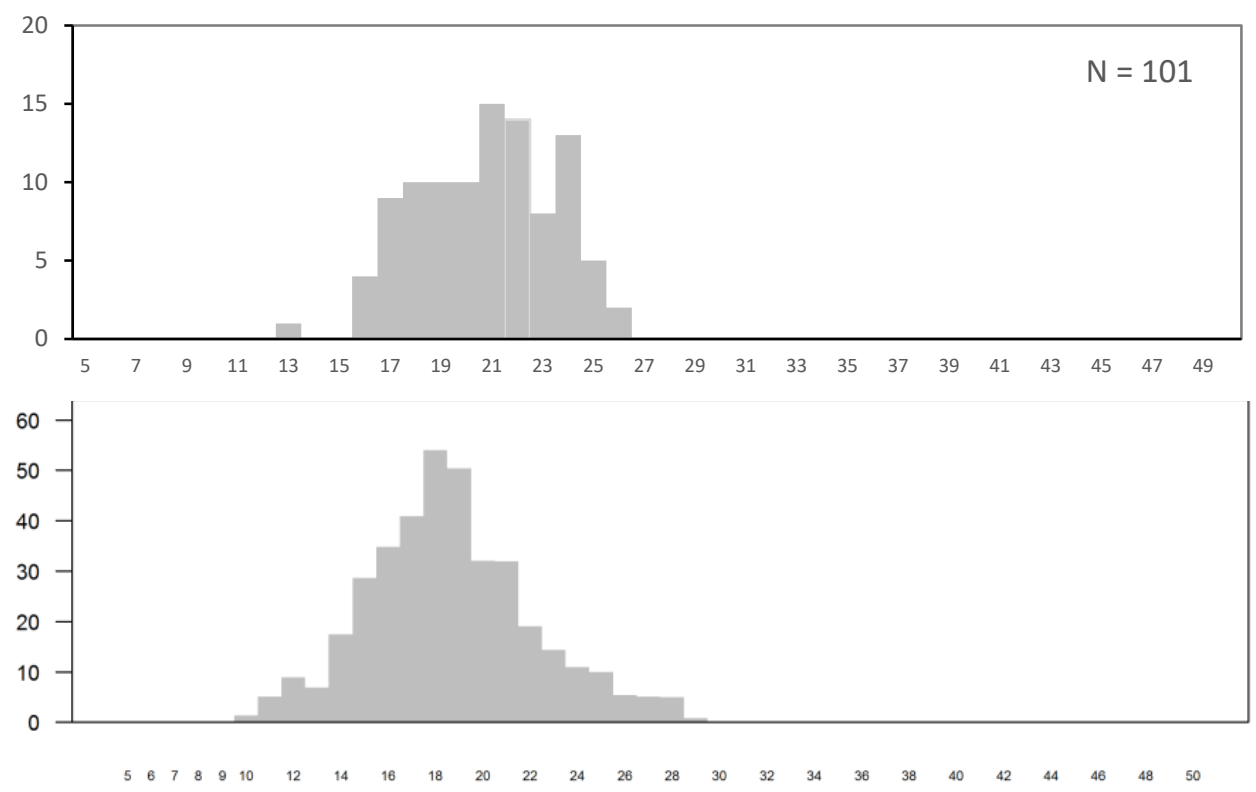

Figuur 2. Boven de lengteverdeling van de schar gemeten tijdens de HSNC pilot. Onder de lengteverdeling van gediscarde schar gevangen met een 100-119 mm boomkor (Verkempynck et al., 2018). 


\section{$4 \quad$ Conclusies en aanbevelingen}

\section{Evaluatie methode}

Door de korte aanloop (of het ontbreken daarvan) van de betrokkenheid van WMR bij dit project en de beperkte mogelijkheid tot het voorbereiden van een plan van aanpak, is deze niet optimaal geweest. De aangeleverde formulieren waren niet het meest efficiënt voor de waarnemer van RWS. Als gevolg hiervan heeft hij gegevens dubbel moeten invullen en zijn in de beginperiode niet alle of niet op de juiste manier gegevens genoteerd. Later is dit aangescherpt, maar dit zou bij een eventueel vervolg verder kunnen worden geoptimaliseerd. Zo is bijvoorbeeld de totale visvangst niet bij alle trekken genoteerd.

Tijdens het werk van de WMR waarnemer aan boord hebben zowel de WMR waarnemer en de RWS waarnemer de vangsten genoteerd. Hieruit bleek dat er relevante verschillen waren in wat er genoteerd was. Met behulp van de aangeleverde foto's viel te achterhalen wat de werkelijke vangst was. Het nakijken van de genoteerde vangst met behulp van de fotoarchieven, is echter voor de hele reis een ondoenlijke zaak. Het gebruik van foto's is beter geschikt voor het ophelderen van onduidelijke of bijzondere vangsten. Een andere conclusie is dat de taak van het doormeten van de visvangst als extra taak voor de RWS waarnemer niet voldoende is voor een nauwkeurig beeld van de vangst. Dit zal mogelijk deels komen door gebrek aan tijd en focus, en deels aan gebrek aan kennis. Ook het verschil in de vangst van schar en harnasmannetjes tussen de pilot, met waarnemers en het vervolg, zonder waarnemers is hier mogelijk aan te wijten. Schar en harnasmannetjes zijn immers soorten die door hun beperkte commerciële waarde wellicht minder op het netvlies staan van vissers.

Tijdens het vervolg was er geen RWS waarnemer aan boord, maar heeft de bemanning zelf treklijsten ingevuld. Dit gebeurde minder uitgebreid en werd aangevuld met een fotobestand van foto's genomen met een aparte camera. Het idee hiervan was dat onduidelijkheden op de treklijsten geverifieerd konden worden. De foto's betroffen helaas enkel foto's van specifieke delen van de vangst, waardoor andere delen van de vangst ontbraken en er geen goed zicht was op de totale vangst. Omdat de foto's pas na afloop werden overgedragen kon hier niet meer in bijgestuurd worden. Wat dat betreft is whatsapp een directer medium, met meer mogelijkheden tot bijsturing. Whatsapp is hierdoor voor het melden van bijzonderheden op zichzelf nuttig, maar wel afhankelijk van het doorgeven van de visser. Zo is de haai niet doorgegeven, waardoor we niet weten om welke soort het ging en of het een beschermde soort betrof. Voor een geslaagde inzet is het dus van belang dat de afspraken hierover scherp zijn en ook uitgevoerd worden.

\section{Evaluatie bijvangst}

Gezien de combinatie van het gebruikte vistuig en het gebied waarin gevist werd, was er weinig verwachting van bijvangst van beschermde soorten. Tijdens dit project is er geen bijvangst geweest van beschermde soorten zoals beschreven op de rode lijst voor Nederland (Tien et al., 2016), wel van soorten die als gevoelig (wijting) of kwetsbaar (stekelrog en makreel) op deze rode lijst werden aangemerkt. Alleen de stekelrog heeft een vermelding op de "List of Threatened and/or Declining Species and Habitats" van de OSPAR conventie (OSPAR, 2008). De stekelrog is in de commerciële visserij een veelvoorkomende bijvangst en valt onder het gedeeld roggen quotum. Deze soorten hebben dus allen niet de status van 'bedreigd', en zijn bovendien maar een enkele keer gevangen. Op basis van de aangeleverde gegevens wordt het vermoeden van de lage kans op het vangen van beschermde soorten bevestigd, desalniettemin kan niet uitgesloten worden dat dit bij een vervolg wel zo zou kunnen zijn. Vooral niet wanneer dit in een ander gebied of periode gebeurt. Ook is de kwaliteit en onafhankelijkheid van de gegevens niet goed genoeg om hier met zekerheid antwoord op te kunnen geven.

De visvangst tijdens deze pilot bestond voornamelijk uit schar (gemiddeld 5,8 per uur), daarnaast werden er met regelmaat andere gangbare commerciële platvis soorten gevangen $(0,75-2,10$ per uur). Hiervan bevind alleen de visserijdruk op tong op dit moment zich boven het MSY limiet, maar 
niet boven het beheerdoel (ICES, 2019c), bovendien is er relatief weinig van deze soort gevangen $(0,75$ per uur). Helaas zijn gegevens van aanlandingen van de commerciële visserij altijd in gewicht gegeven en zijn er tijdens dit project alleen aantallen per soort genoteerd. Desalniettemin is het bij vergelijking duidelijk dat gezien de omvang van de visvangst de schade op de bestanden van de commerciële soorten nihil is. Alleen al wanneer we kijken naar de hoeveelheid discards per uur voor schar en schol (die wel in aantallen beschikbaar was) is het direct duidelijk dat het hier om geringe aantallen gaat. De hoeveelheid harnasmannetjes die met name tijdens de pilot gevangen werd is wel vrij hoog in vergelijking met wat er gediscard wordt met vergelijkbare tuigen in de commerciële visserij (waar totale vangst harnasmannetjes is discard). Omdat dit geen commerciële soort betreft zijn er geen bestandschattingen van, maar er is geen reden aan te nemen dat deze soort bijzonder kwetsbaar is. Ook de gemiddelde visvangst van 1,6 kilo per trek is marginaal te noemen.

Tijdens vissen met een bodemtuig zal er altijd sprake zijn van negatieve gevolgen voor de natuur. Of dit in verhouding staat tot het doel en of dit acceptabel is, is een vraag die hier niet beantwoord kan worden. Wel kan uit de evaluatie van de bijvangst van deze pilot geconcludeerd worden dat de negatieve gevolgen van deze werkzaamheden op het ecosysteem minimaal zijn.

\section{Aanbevelingen}

Mochten dit soort activiteiten in de toekomst ingezet worden dan is het aan te bevelen om Wageningen Marine Research of een vergelijkbaar instituut hier in een vroeg stadium bij te betrekken. Op basis van het beoogde tuig in combinatie met gebied en periode zou Wageningen Marine Research met behulp van de aanwezige kennis een analyse/voorspelling kunnen doen van de ecologische impact en bijvangst. Ook waarnemersreizen blijken in dit geval een grote meerwaarde te hebben om een goed beeld te krijgen van de bijvangst, maar vooral ook om de "zelf registratie" of andere methode op waarde te schatten. Meer waarnemersreizen en een evaluatie en terugkoppeling op het functioneren van de zelfregistratie of andere methode na de eerste waarnemersreis zouden een belangrijke bijdrage kunnen leveren aan de bruikbaarheid van de gegevens. Alhoewel bij zelfregistratie de bereidwilligheid en capaciteit van de bemanning om registratie uit te voeren, doorslaggevend blijft. 


\section{$5 \quad$ Kwaliteitsborging}

Wageningen Marine Research beschikt over een ISO 9001:2015 gecertificeerd kwaliteitsmanagementsysteem. Dit certificaat is geldig tot 15 december 2021. De organisatie is gecertificeerd sinds 27 februari 2001. De certificering is uitgevoerd door DNV GL.

Het chemisch laboratorium te IJmuiden beschikt over een EN-ISO/IEC 17025:2017 accreditatie voor testlaboratoria met nummer L097. Deze accreditatie is geldig tot 1 april 2021 en is voor het eerst verleend op 27 maart 1997; deze accreditatie is verleend door de Raad voor Accreditatie. Het chemisch laboratorium heeft hierdoor aangetoond in staat te zijn op technisch bekwame wijze valide resultaten te leveren en te werken volgens de ISO17025 norm. De scope (L097) met de geaccrediteerde analysemethoden is te vinden op de website van de Raad voor Accreditatie (www.rva.nl).

Op grond van deze accreditatie is het kwaliteitskenmerk $\mathrm{Q}$ toegekend aan de resultaten van die componenten die op de scope staan vermeld, mits aan alle kwaliteitseisen is voldaan. Het kwaliteitskenmerk Q staat vermeld in de tabellen met de onderzoeksresultaten. Indien het kwaliteitskenmerk $Q$ niet staat vermeld is de reden hiervan vermeld.

De kwaliteit van de analysemethoden wordt op verschillende manieren gewaarborgd. De juistheid van de analysemethoden wordt regelmatig getoetst door deelname aan ringonderzoeken waaronder die georganiseerd door QUASIMEME. Indien geen ringonderzoek voorhanden is, wordt een tweede lijnscontrole uitgevoerd. Tevens wordt bij iedere meetserie een eerstelijnscontrole uitgevoerd. Naast de lijnscontroles wordende volgende algemene kwaliteitscontroles uitgevoerd:

- Blanco onderzoek.

- Terugvinding (recovery).

- $\quad$ Interne standaard voor borging opwerkmethode.

- Injectie standard.

- Gevoeligheid.

Bovenstaande controles staan beschreven in Wageningen Marine Research werkvoorschrift ISW 2.10.2.105.

Indien gewenst kunnen gegevens met betrekking tot de prestatiekenmerken van de analysemethoden bij het chemisch laboratorium worden opgevraagd.

Indien sprake is van onbeheerste kwaliteit worden passende maatregelen genomen. 


\section{Literatuur}

Ellis, J. R., McCully Phillips, S. R., \& Poisson, F. (2017). A review of capture and post-release mortality of elasmobranchs. Journal of Fish Biology, 90(3), 653-722.

Enever, R., Revill, A.S., Caslake, R., Grant, A., (2010). Discard mitigation increases skate survival in the Bristol Channel. Fisheries Research, 102: 9-15.

ICES. 2017. Dab (Limanda limanda) in Subarea 4 and Division 3.a (North Sea, Skagerrak and Kattegat). In Report of the ICES Advisory Committee, 2017. ICES Advice 2017, dab.27.3a4, 11 pp. DOI: $10.17895 /$ ices.pub.3106

ICES. 2019a. Flounder (Platichthys flesus) in Subarea 4 and Division 3.a (North Sea, Skagerrak and Kattegat). In Report of the ICES Advisory Committee, 2019. ICES Advice 2019, fle.27.3a4, 10 pp. https://doi.org/10.17895/ices.advice.4860

ICES. 2019b. Plaice (Pleuronectes platessa) in Subarea 4 (North Sea) and Subdivision 20 (Skagerrak). In Report of the ICES Advisory Committee, 2019. ICES Advice 2019, ple.27.420, https://doi.org/10.17895/ices.advice.4870

ICES. 2019c. Sole (Solea solea) in Subarea 4 (North Sea). In Report of the ICES Advisory Committee, 2019. ICES Advice 2019, sol.27.4, https://doi.org/10.17895/ices.advice.4873

ICES. 2019d. Turbot (Scophthalmus maximus) in Subarea 4 (North Sea). In Report of the ICES Advisory Committee, 2019. ICES Advice 2019, tur.27.4, https://doi.org/10.17895/ices.advice.4876

OSPAR Commission (2008) OSPAR List of Threatened and/or Declining Species and Habitats. Reference Number: 2008-6. (http://www.ospar.org/documents?d=32794).

Mandelman, J. W., Cicia, A. M., Ingram Jr, G. W., Driggers III, W. B., Coutre, K. M., and Sulikowski, J. A. (2012) Short-term post-release mortality of skates (family Rajidae) discarded in a western North Atlantic commercial otter trawl fishery. Fisheries Research, 139: 76-84.

Tien, N.S.H., Heessen, H., Kranenbarg, J. \& Trapman, B. (2016) Achtergronddocument Rode lijst vissen 2011: zoutwatervissen. Ijmuiden: IMARES Wageningen UR. IMARES-rapport C021/16. http://library.wur.nl/WebQuery/wurpubs/fulltext/378196 .

Verkempynck, R., van Overzee, H., \& Dammers, M. (2018). Discard self-sampling of Dutch bottomtrawl and seine fisheries in 2014-2016 (No. 18.007). Stichting Wageningen Research, Centre for Fisheries Research (CVO). 


\section{Verantwoording}

Rapport C021/20

Projectnummer: 4316100200

Dit rapport is met grote zorgvuldigheid tot stand gekomen. De wetenschappelijke kwaliteit is intern getoetst door een collega-onderzoeker en het verantwoordelijk lid van het managementteam van Wageningen Marine Research

Akkoord:

Ralf van Hal

Onderzoeker

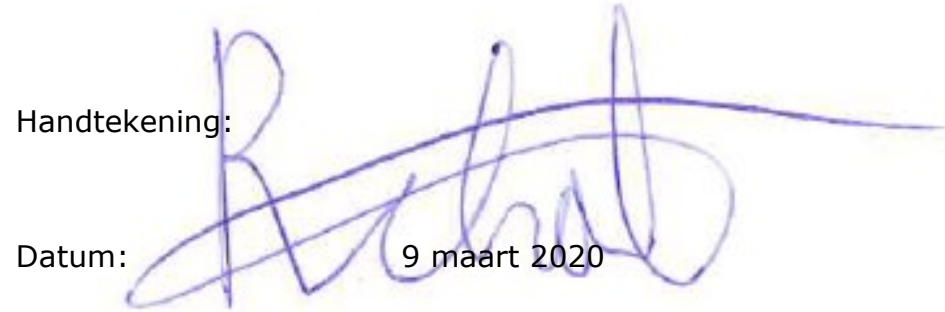

Akkoord:

Jakob Asjes

Manager Integratie

Handtekening:

Datum:

12 maart 2020 
Wageningen Marine Research

T: +31(0)317480900

E: marine-research@wur.nl

www.wur.nl/marine-research

Bezoekers adres:

- Ankerpark 27, 1781 AG Den Helder

- Korringaweg 7, 4401 NT Yerseke

- Haringkade 1, 1976 CP IJmuiden
Wageningen Marine Research levert met kennis, onafhankelijk wetenschappelijk onderzoek en advies een wezenlijke bijdrage aan een duurzamer, zorgvuldiger beheer, gebruik en bescherming van de natuurlijke rijkdommen in zee-, kust- en zoetwatergebieden.

Wageningen Marine Research is onderdeel van Wageningen University \& Research. Wageningen University \& Research is het samenwerkingsverband tussen Wageningen University en Stichting Wageningen Research en heeft als missie: 'To explore the potential of nature to improve the quality of life'

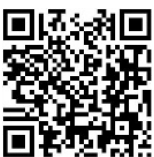

